\title{
Love Thy Neighbor as Thyself: Community Formation and the Church
}

\author{
THOMAS D. JEITSCHKO \\ Department of Economics \\ Michigan State University
}

East Lansing, MI 48824

U.S.A.

jeitschk@msu.edu

\author{
SÉAMUS O’CONNELL \\ Faculty of Theology \\ Maynooth College \\ County Kildare \\ Ireland
}

seamus.g.oconnell@may.ie

$$
\begin{gathered}
\text { ROWENA A. PECCHENINO }{ }^{1} \\
\text { Department of Economics } \\
\text { Michigan State University } \\
\text { East Lansing, MI } 48824 \\
\text { U.S.A. } \\
\text { rowenap@msu.edu }
\end{gathered}
$$

Running Title: Love Thy Neighbor

August 9, 2006

${ }^{1}$ Corresponding author: phone + 517355 5238, fax + 5174321068 . 


\begin{abstract}
The church has played a central role in establishing and maintaining, as well as undermining, communities throughout modern history. In this paper we explore some of the mechanisms through which the church can coordinate individual behavior to achieve improvements in individual and social welfare, and reveal the ways in which the church can fail, causing established communities to founder or dissolve. In our model inherently religious individuals may become trapped in a secular equilibrium that is strictly dominated by a religious equilibrium in which individuals' actions bestow positive external benefits on other community members. The church, via its teachings, clergy and ministries, reveals the benefits of coordinated behavior, both in this world and in the world to come, and the costs of uncoordinated behavior, separation from God and one's fellow man, to induce community members to take actions which are both individually and socially beneficial. External forces, such as the state and secular society, and internal forces, such as doctrinal disputes, inconsistencies, and incoherence, can reduce a church's ability to coordinate, to the detriment of all.
\end{abstract}

Keywords: Economics of Religion, Spirituality, Community Formation, Coordination Failures

JEL classifications: I19 
You shall love your neighbor as yourself. There is no commandment greater...

Churches have long played a central role in coordinating community life. This role is sometimes writ large, such as when the head of an established church has key governing duties on a national or international scale, or small, such as when the rural parish priest sees to the spiritual and temporal well being of his flock. Since the institutional church is seldom absent when communities form, grow and die, we examine the role of churches in community formation and establish a link between the strength and quality of faith communities and social welfare. We further explore the balancing of church and state roles in these processes, and the costs of community dissolution. We examine these phenomena in a static model of coordination with strategic complementarities. Using game theoretic techniques we endogenize the interactions among individuals, adding churches as institutional structures that provide the spiritual and temporal incentives-coordinating mechanisms-for group rather than individually oriented actions.

The coordinating role can be played by churches through ethos in which the individual is to place the community over the self, as can be seen in key texts like Paul's letters, the Lord's Prayer and the fourth century Nicene Creed. Churches, concerned with the welfare of their members and of the wider community, become guides to individual and community betterment by providing spiritual subsidies or taxes, implicit or explicit rewards for investments in one's own spirituality and in one's community, or penalties for failing to do so. Thus, churches which, unlike present focussed governments, are not prone to time inconsistent behavior, can enable their members to internalize the external effects of their actions on other members, both in their faith community and society at large, and thereby induce better outcomes with higher wellbeing 
for all community members. But, if churches or the leaders thereof fail to live what they preach, or if their role is delegated to or crowded out by the state or the market, their ability to coordinate and sustain communities will diminish and society as a whole may suffer.

\section{The Church and the Community}

The major monotheistic religions, Judaism, Christianity, and Islam are all community religions. Members of these faith communities come together to worship and are bound to each other by ties of spiritual kinship. Thus, to achieve their basic communitarian goals, institutional structures - the congregation, the parish, the world Church, the universal Church-have been developed. It is these structures, their reflection in the Christian Scriptures, the incentives used to maintain them, and their potential weaknesses that we first describe.

\subsection{Importance of Community-In Scripture}

The centrality of community and of communal interaction and the origins for the institutions to facilitate them can be seen in the New Testament (NT). Christian Scriptures provide a key set of models and motivations for Christians as they relate with each other and form communities. While we examine most closely Christian Scripture, similar dynamics operate in the Jewish and Islamic Scriptures.

The core of the call to community can be found in the scriptural exhortation to love your neighbor for this imposes a mode of behavior on all believers to treat others well (Mark 12:31). Who one's neighbors are, and thus what the limits of one's community are, is not defined narrowly by faith or ethnicity (Luke 10:25-29). Further, the individual cannot choose not to respond to another's need because, by definition, that need is now his as well. This does not make community a meaningless construct by 
including everyone, but it does suggest that one cannot turn one's back on those in need just because they are not of one's community narrowly defined.

But the call to community brings obligations-both for the wealthy and for one's peers. The rich are called, first of all to see the "poor at their gate" (Luke 16:26). From a Gospel perspective, ignoring others' needs given one's relative wealth is both an offence against one's community and an offense against God, since according to scripture wealth is a gift of God which should be used to benefit the community as a whole (Scott, 1990, p. 137). The demand to compassion and action is not limited to the wealthy. The Book of Acts reflects the communitarian ideal put before the early Christians to share all resources for the betterment of the community (Acts 4:32).

Bartchy (2002) suggests that Luke presents God as a "communityforming and community sustaining power" (p. 91). This community of believers brought together by God, which is reflected in the early chapters of Acts, is one's surrogate family, and it is this family's welfare, rather than one's own or one's own kinship group's welfare, that is of the utmost importance. And all contribute; each caring for the others, all being essential to the whole. In this way the idea of community and the implicit and explicit admonition to put community before self is institutionalized.

The unity of the early communities is constantly under threat. Paul's First Letter to the Corinthians is occasioned by divisions and factions among the nascent Christian community. His vision for them and that to which he calls them is a unity in mutual service, especially in the service of the financially and socially most disadvantaged among them.

Paul emphasizes that more can be achieved and all can be made better off, both in the here and now and eschatologically, by working together and caring for each other. In fact, to achieve what is possible requires that all work together, that gifts be shared (1 Cor 12). 
But, Christ asks more than that by placing demands on those most able and most gifted to give more, to serve their communities. Knowing human nature and the strength of the desire to succeed in this life, success is redefined. Spiritual wealth, through service to God and community, given its value both in this life and the next, trump material wealth with value only in the here and now. That is, in its earliest manifestations, the Christian church placed the welfare of the community over the welfare of each individual member thereof.

\subsection{Community formation during the Patristic period}

During the first few centuries of the Common Era the Christian church established itself as an institution rather than a set of largely independent Pauline congregations which were often under stress from both within, see 1 Cor, and without. The reality of community required more structure than that outlined in the Scriptures. For example, baptism, the initiation in the Christian community, symbolizing a "passage from one population to another ... a new form of identity," (Johnson 1998, p. 77) was supposed to bring the earliest Christians to the ultimate mystery of Christ. Yet, they sought further initiations into higher mysteries, a belief pattern consistent with their pagan religious experience. To survive and to further its communitarian goals the church had to adapt (Johnson, 1998). Persecution of Christian communities throughout the Roman Empire revealed the importance of "maintaining ecclesiastical unity, pastoral integrity, and consistent standards of membership" (Hayes, 2002, p. 155). This required leaders and a consistent, respected leadership structure, but little in the Gospels, or in Acts, or in Paul's letters suggested how leaders would be chosen, or the extent of their power beyond their own congregation. The church as a universal institution did not yet exist. Leaders, the bishops of the early church, were required to guide the communities (Young, 2002), where the bishop was God's representative on 
earth. As the community grew, the need to maintain it, that is, to coordinate the activities of members to the common good, led to the ordination of priests and the hierarchical institutional structure of the church, both of which conferred authority and provided a leadership (coordinating) structure.

\subsection{The church in community formation/urbanization}

At the end of the Patristic period (late antiquity), the Roman Empire was collapsing, and the security of individuals in society was constantly under threat. The social structure imposed by the Empire was slowly breaking down and it was, as Peter Brown (1981) suggests, the church that offered its current members and the pagans it wished to evangelize a community structure, an extended family, but one not based on kinship-while the church provided an ordered society for the living.

Katherine Lynch (2003) argues forcefully that the medieval Church, like the early Church, provided the intellectual foundation and organizational model for community life. Cities of the medieval and early modern period were characterized by high mortality, large numbers of temporary and permanent migrants, small families, and many single people. There were very limited social possibilities (Knuth 1992). While, at one level Church structures resisted the development of new forms of religious life (Peters 1991), at another there emerged from the life of the Church models for support networks and the framework upon which communities were built. Community bonds were formed between the believers who made up the Church. Voluntary kinship relationships, such as godparenthood, could be created. This pseudo kinship relationship, exceptionally important in times of high mortality, was a spiritual rather than a blood relationship, and as such it carried no right of inheritance. Rather it was built on mutual assistance and gift-voluntary ties that bind-rather than strategic considerations-cooperation and communi- 
tarian objectives were institutionalized.

When kinship ties of family or marriage were absent, single individuals, especially women, were still able to create surrogate families by the formation of residential communities. These communities of single lay women, were patterned after, and often associated with, monasteries. However, in contrast to female religious (e.g., nuns), these residents were not required to be cloistered. These women, known as beguines, were religiously observant, were dedicated to the ideals of chastity and charity, but worked in the market to support themselves rather than relying on the charity of others or their families to support them. These beguinages were voluntary associations where individuals joined together for the betterment of all within their own community, that the individual beguines were concerned with the welfare of those in the broader community, and that they were associated with and patterned after religious orders: the institutions of the church were emulated by secular society.

Still looser ties, but important nonetheless, were forged by membership in confraternal societies. These societies, often open to both men and women, married and single, were nonresidential religious organizations built on the premise of the importance of a community based devotional life, of mutual assistance in time of need, and of charity to those less fortunate in society. This charity was directly given by society members to the poor. Communal links were forged via direct contact. They provided support networks and requirements of aid and assistance not hampered by ties of kinship (and thus of inheritance). While they were lay organizations, a member of the clergy would generally act as chaplain and moral guide. The sharp divisions between the sacred and the secular did not yet exist, but a stable communitarian model had been developed in which the church played a central coordinating role.

de Swaan (1988) contends that parish communities as well as urban centers could not have formed without a system of poor relief, and it 
was the clergy who organized and facilitated that relief. To establish a viable system it was necessary to ensure that all involved played their parts-that is, there were no free-riders either among those giving the charity or those receiving the charity. This required a mutually agreed set of rules (a commonly agreed social welfare function), trust that if you played by the rules you would receive your reward, oversight and persuasion to preclude free riders and other forms of cheating. Ensuring that these requirements were met fell to the clergy. Those providing the charity did so for reasons both practical-personal and economic security-and spiritual-since they would be prayed for by the recipients of their largesse. Moreover, being charitable was a duty and obligation of all Christians who would be rewarded in the next life if not in this. To the extent that charity was a public activity, and it was since those who gave wanted to be sure that their generosity was recognized and rewarded, it was capable of being monitored. Thus, social control could be exerted.

As countries developed, the universal power and wealth of the church diminished or became fractured, and cities grew, civic duty replaced religious charity as the source of poor relief. Compulsion (taxation) replaced voluntary (if incentivized) cooperation. And, while material wealth has clearly increased over the two centuries or so of state domination of poor relief, community cohesion has weakened.

\subsection{Challenges to church led community formation today}

Today the role of the Christian church has moved from the center to the periphery (Hester, 2002), making it harder for it to fulfill its pastoral (coordinating) role even narrowly for its own community. What appears to be required for success is high market density, a large enough community of faith, which leads to higher participation and better economic outcomes (Gruber, 2005). Although challenged to sustain themselves in a changing environment (Webster, 2002; Hester, 2002; Volf, 2002), faith 
communities maintain their concern and commitment to the broader, multicultural and multifaith community of which they are a part. When faith communities seek to help build a sustainable multicultural community they are often actively excluded by statutory agencies and secular funding agencies when they apply for outside funding for community regeneration and renewal projects (Smith, 2002). Perhaps this is because they have been ignored or disdained by theorists of multiculturalism whose perspective is decidedly secular and at least implicitly anti-religious (Modood, 1999). This is true even though many who are members of this multicultural community, and are the disadvantaged and socially excluded, identify themselves first by their religious affiliation (Farnell, 2001). Yet it remains that, although often marginalized, "religious communities maintain a role as a forum for social interaction, mutual support and personal networking" (Smith, 2002, p. 168): they can provide the coordinating mechanism.

While churches are, grudgingly, recognized as useful and perhaps even a necessary component of community revitalization, they are also acknowledged as essential for the maintenance of civil society in modern Western democracies. This is because "egalitarianism in a commercial republic such as the United States unleashes a materialistic quest. At this juncture, faith communities, not simply as a goad and a kind of adjunct feature of the civic but, rather, in their robust specificity and particularity, are vital. Why? Because such traditions and communal institutions serve as a chastening influence on striving ambition by inspiring contrary urges that draw people into community and away from narrow materialism. Religion, in Toqueville's words, helps to 'purify, control, and restrain that excessive and exclusive taste for well-being human beings acquire in an age of equality.' Tocqueville surely had in his sights the early covenantal tradition and its living remnants. The notion of covenant is one that stresses mutual accountability of persons to one another and before God. 
This creates and sustains 'a kind of moral equality among people' (Elshtain, 2001, pp. 44-45). Peter Drucker (Forbes, 1998) echoes Tocqueville by stating that the pastoral church is the most important social movement of our time because it provides community, a sense of belonging, gives meaning to one's life, and pastoral care for those in need.

\section{A Model of Church and Community}

In order to understand and appreciate the potential and actual role of the church in community, we develop a model similar to Cooper's (1999) basic model of coordination failure games, with an institutional emphasis similar to Bowles (2004). In these games individual agent's choices affect the payoffs to other agents' choices, but this external effect is not priced by the market. As a result, agents may make choices that are individually rational, but result in a Pareto inferior equilibrium outcome. The problem is that without a functioning market they may be unable to coordinate their choices. But, because of the nature of the interrelationship among payoffs, a market will not open, which leaves "sunspots" or "animal spirits" (see Weil, 1989) or an institution, such as the government, or in our case the church, to play the coordinating role.

In many macroeconomic applications of the coordination failure model, the role played by the government is as often stabilizing, (e.g., Diamond and Dybvig, 1983), as it is-perhaps inadvertently - destabilizing, (see Kydland and Prescott, 1977, or Barro and Gordon, 1983). The problem is that the government must be able to commit itself to taking specific actions (and thus to be able to commit future governments as well as the current government to taking these actions) without having the mechanism to do so. Churches, however, have two channels through which they can achieve coordination. First, through their foundational teaching (scripture and doctrine), which provides a commitment mechanism and 
assesses implicit spiritual penalties and rewards. And second, through their clergy, who have close relationships with the members of their congregations and who communicate the church's commitment, the cost of the penalties and the benefits of the rewards, who, thus, facilitate or even achieve coordination both in the here and now as well as eschatologically.

Our model also bears a close kinship to Hollander's (1990) model of social exchange and the Brekke et al. (2003) model of moral motivation. These papers ask why individuals take actions that are socially, if not what is thought to be individually, optimal. Hollander suggests it is because we seek the approval of our fellows. Brekke et al., suggest that it is because we, as individuals, want to maintain our self-image as socially responsible individuals, and define the socially responsible ideal via Kant's Categorical Imperative. We take a step further back and ask what the foundations of these moral motivations are, and find them both in the ideal of community, consistent with Kant, but also in man's seeking for divine in addition to human approbation, a situation in which the reward for moral behavior may not come in this life (Bonhoeffer, 1959).

Finally, our model also shares some features with Tirole's (1996) model of collective reputation. Here the collective reputation is mediated through the moral authority of the church and behavioral norms held to by the believers following the tenets of their faith. Collapse of this moral authority, like a reputation squandered, cannot be easily reversed, so communities fracture just as a firm loses market share.

\subsection{The Individual}

Consider a society in which there are $n+1$ agents who have a potential joint religious affiliation. ${ }^{1}$ Each agent $i=\{1,2, \ldots, n+1\}$ has individual preferences defined over leisure time, $l$, material goods, $m$, and their

\footnotetext{
${ }^{1}$ In this paper we assume a single church. In future work we will look at multiple churches which may positively or negatively interact.
} 
spirituality, $\sigma$, given by

$$
u(l, m, \sigma)=(l-\lambda)^{\alpha}(m-\mu)^{\beta} \sigma,
$$

where

$$
\sigma(r, \bar{d} \mid h)=h(1+r)^{\gamma_{T}}(1+\bar{d})^{\gamma_{M}}
$$

The agent's spirituality is defined over time spent in religious observance and other church related activities, such as volunteering at a church sponsored charity, $r$, and donations made to one's church relative to one's income, $\bar{d} .^{2}$ The multiplier $h$, discussed in greater detail below, denotes potential spiritual rewards and penalties that stem directly from theological concerns and indirectly from one's choices.

The amount of time spent in leisure activities that is considered "socially necessary" is denoted by $\lambda$; and $\mu$ is the "socially necessary" amount of material consumption. Socially necessary time-use and material consumption are the outcome of socio-cultural imperatives, such as keeping up with the Joneses, both in terms of goods consumed and activities attended. ${ }^{3}$

The constraints faced by the agent are:

$$
\begin{array}{cl}
\text { Time: } & T \equiv 1=l+r \quad(\text { with } \lambda<T) \\
\text { Money: } & M=p m+d \quad(\text { with } \mu<M) \\
& \Leftrightarrow \quad \bar{d}=\frac{M-p m}{M}, \quad \text { or } \quad m=\frac{M}{p}(1-\bar{d}),
\end{array}
$$

where $p$ is the price of material goods.

\footnotetext{
${ }^{2}$ This normalization of donations follows from Mark 12:41-44 in which the poor widow's generosity is contrasted with the relative miserliness of the crowd.

${ }^{3}$ That individuals gauge their happiness not by what they have, per se, but rather by how what they have compares with what their peers have has been found by Blanchflower and Oswald (2004) among others. We represent the comparison consumption and leisure activities as social norms.
} 
The parameter restrictions are:

$$
\begin{gathered}
\alpha, \beta, \gamma_{T}, \gamma_{M}>0 \\
\alpha+\beta \leq 1 .
\end{gathered}
$$

Thus, the benefit to consumption of material goods and leisure diminish at the margin, but this need not be the case for one's spirituality.

\subsection{The Church}

Let $\chi(R, D, \rho)$ denote the institutional strength of the agent's church or congregation and index the agent whenever needed by $i$. Here

- $R:=\sum_{j \neq i} r_{j}$ is the amount of time devoted by the agent's fellow religious community members;

- $D:=\sum_{j \neq i} d_{j}+d_{S}$ are the financial resources available to the congregation independently of the agent's contributions, where $d_{S}$ are funds from other sources, such as the state. Finally,

- $\rho$ measures theological factors affecting the institutional strength of the church, e.g., foundational teachings of the church and church leadership (at all levels of the Church hierarchy).

We assume that $\chi$ is increasing at a decreasing rate in all three of its arguments. Specifically, we let

$$
\begin{gathered}
\chi(R, D, \rho)=R^{\kappa_{1}} D^{\kappa_{2}} \rho^{\kappa_{3}}, \\
\text { with } \kappa_{k}>0, \forall k=1,2,3 \text {, and } \sum_{k} \kappa_{k}=1 .
\end{gathered}
$$

Thus, a church that lacks a coherent belief system or has ineffective leaders $(\rho=0)$, or in which none of its members devotes any time to religious practice $(R=0)$, or which is devoid of resources $(D=0)$, also has no institutional strength. 
Notice, institutional strength has both a temporal and a spiritual dimension, and it is through this spiritual dimension-which links actions today with eschatological rewards or punishments - that the church provides spiritual incentives for individually and community oriented good behavior.

\subsection{The Church \& The Individual}

A relationship between the church and the individual is provided through the individuals' spirituality function, $\sigma$, and potential spiritual penalties, $h$. Thus, the institutional strength of the church has a positive effect on the agent's benefit from religious activity, both in terms of time spent in religious pursuits and in terms of resources devoted to religion. This is formalized in the following assumption.

Assumption 1 The church strengthens the individual's spirituality by increasing the agent's marginal utility from time spent in religious pursuits and from charitable giving. Thus, for $S=T, M$ let $\gamma_{S}=\gamma_{S}(\chi)$ be continuous and twice differentiable, with

$$
\begin{aligned}
& \gamma_{S}(0) \geq 0, \lim _{\chi \rightarrow \infty} \gamma_{S}(\chi)=\infty \quad \text { and } \\
& \gamma_{S}^{\prime}>0, \quad \gamma_{S}^{\prime \prime} \leq 0 \quad \forall \chi>0 ; \quad S=T, M .
\end{aligned}
$$

Given this assumption, we study the indirect effect that the church has on leisure time and material consumption, given that it directly affects time spent in religious pursuits and charitable giving.

Consider now the multiplier $h$. For a large set of agent choices, we consider $h$ to be a constant multiplier (which can be normalized to 1 ). However, we also include the possibility that an individual can be assessed a "spiritual penalty" in circumstances in which adherence to minimal religious covenants is violated. If these can be represented by a 
minimum of religious activity, $r_{\min }(\rho)$, or charitable giving, $\bar{d}_{\min }(\rho)$, one can think of $h$ as an indicator function,

$$
h(r, \bar{d})=\left\{\begin{array}{lll}
\bar{h} \equiv 1 & \text { if } \quad r \geq r_{\min }(\rho) \wedge \bar{d} \geq \bar{d}_{\min }(\rho), \\
\underline{h}<\bar{h} & \text { if } \quad r<r_{\min }(\rho) \vee \bar{d}<\bar{d}_{\min }(\rho) .
\end{array}\right.
$$

Here $\underline{h}$ may be equal to 0 , or even negative, e.g., $\underline{h}=-1$. Indeed, if one were to include realizations of $h$ in the after-life, one might also consider $\bar{h}=+\infty$ or $\underline{h}=-\infty$.

See, for example, Matt 5:22, Mark 9:43, Luke 3:9, or Rev 21:8, where behavioral incentives are specified. That is, according to the Catholic catechism, "the chief punishment of hell is eternal separation from God, in whom alone man can possess the life and happiness for which he was created and for which he longs" (Catechism of the Catholic Church, paragraph 1035). These penalties represent behavioral inducements which define minimally acceptable behavior of an individual vis-à-vis God and as a member of the community of men. The minima depend on church teachings, $\rho$, and may differ from church to church.

\section{The agent's time allocation problem}

Given the model of church and community, consider now how an agent acts within the community and how this affects himself and others.

For now we consider only cases in which $h=1$ or, equivalently, cases in which the agent's decisions are not affected by the presence of the $h$ multiplier. Let $v(M)$ denote the agent's utility associated with income $M$ when it is optimally allocated between material consumption $m^{*}$ and religious contributions $\bar{d}^{*}$, i.e.,

$$
v(M):=\frac{u\left(l, m^{*}, \sigma\left(r, \bar{d}^{*}\right)\right)}{(l-\lambda)^{\alpha}(1+r)^{\gamma_{T}}} .
$$


Then the agent's time-allocation problem is given by

$$
\begin{gathered}
v(M)(l-\lambda)^{\alpha}(1+r)^{\gamma_{T}} \longrightarrow \max _{\{l, r\}} \text { s.t. } l+r=1 \text { and } l, r \geq 0 \\
\Leftrightarrow \quad v(M)(1-r-\lambda)^{\alpha}(1+r)^{\gamma_{T}} \longrightarrow \max _{\{r\}} \quad \text { s.t. } r \in[0,1]
\end{gathered}
$$

The first order conditions of the modified objective are:

$$
\begin{gathered}
-\alpha v(M)(1-r-\lambda)^{\alpha-1}(1+r)^{\gamma_{T}}+\gamma_{T} v(M)(1-r-\lambda)^{\alpha}(1+r)^{\gamma_{T}-1} \\
=-\alpha(1+r)+\gamma_{T}(1-r-\lambda) \leq 0 \\
\text { and } \quad r \geq 0
\end{gathered}
$$

with at least one of the two inequalities holding with equality. So, using br as a mnemonic for "best response," the agent's optimally chosen time spent in religious pursuits is given by

$$
r^{b r}=\max \left\{0, \frac{\gamma_{T}(1-\lambda)-\alpha}{\alpha+\gamma_{T}}\right\} .
$$

Given Assumption 1, we would like to ascertain when agents obtain an equilibrium in which they are religiously observant, and how such an equilibrium is affected by parameter values, including such factors as church teachings. However, we do not preclude the possibility that, despite agents valuing their spirituality, there are outcomes in society in which there is no religious activity. That is, we assume that absent a functioning church (i.e., $x=0$ ), individuals' marginal utility from leisure exceeds that from religious activity. Formally,

Assumption 2 Absent a functioning church, the marginal rate of substitution between religious activities and leisure is less than one, i.e.,

$$
\left.\frac{\partial u / \partial r}{\partial u / \partial l}\right|_{\chi=0}<1
$$

An implication of Assumption 2 is that absent a functioning church, i.e., whenever $x=0$, the individual will choose not to spend time in religious activity despite being religious. Formally, 
Lemma 1 (Potential for Coordination Failure) Although agents are spiritual $\left(\gamma_{T}>0\right)$, an implication of Assumption 2 in conjunction with Equation (??) is that there always trivially exist equilibrium configurations in which there is no religious activity.

While we do care about circumstances that can lead to such equilibrium outcomes, we are not primarily interested in trivial coordination failure outcomes. It is therefore important to determine under what circumstances an equilibrium without religious activity is the unique outcome, rather than simply a coordination failure outcome.

\subsection{Secular and Religious Equilibrium}

Taking $h=1$ as given, it can be shown that even when $R, D, \rho>0$, yielding $\chi>0$ so that the church is potentially viable, an agent may be best off without any religious participation (which, by symmetry, is then true for all agents). In technical terms, an equilibrium in which no-one participates in religious activity is remarkably stable. Thus, even (the potential for) religious dedication and (the potential for) financial dedication to one's religious community is not sufficient to support societal outcomes with active religious participation, whenever church moral authority is weak as a result of inconsistencies, incoherence, discontinuities, etc. in church teachings or due to failures in church leadership.

Proposition 1 (Unique Secular Equilibrium) Given finite time and finite financial resources of a (potential) congregation, an equilibrium in which agents sustain religious participation does not exist if the church does not have sufficient moral authority, i.e.,

$$
\forall \bar{R}, \bar{D}<\infty \quad \exists \underline{\rho}>0 \quad \text { s.t. } \quad \forall \rho<\underline{\rho} \quad n r_{i}^{b r}<\bar{R} .
$$

Thomas Hobbes in his philosophical treatise Leviathan described humans as innately religious, and suggested that religion provides men with 
behavioral norms that ensure a civil society in which both earthly and divine laws are promulgated and followed. But, since the authority of religion, the church, depends on those who lead it, that authority can be undermined by those leaders behaving in ways contrary to their own teachings. To Hobbes this explained the expulsion of the Roman Catholic Church from England, but also the downfall of those leading the Reformation. Without the authority of the church, man falls into a state of "war" with each individual seeking his own end without concern for others. This state describes both our trivial and our secular coordination failure equilibria. While life in these equilibria will not be "solitary, nasty, brutish, and short," (Hobbes, 1958 [1651], p. 107), they will bring individuals less happiness (personal fulfilment) than the religious equilibrium.

Nevertheless, while a secular equilibrium always exists, when the church becomes stronger, there also exists a religious equilibrium.

COROLlARY 1 (RELIGIOUS EQUILIBRIUM) A symmetric equilibrium with a high level of religious activity exists whenever $\rho \geq \underline{\rho}$. Moreover, whenever $\rho>\rho$, there exist two symmetric Pareto-rankable religious equilibrium outcomes. The Pareto dominant one entails a higher level of religious activity and is stable, whereas the inferior one is not stable. In both cases, religious activity is (non-uniquely) implied by

$$
0<r_{i}^{e q}=r^{e q}=\frac{\gamma_{T}\left(\left(n r^{e q}\right)^{\kappa_{1}} D^{\kappa_{2}} \rho^{\kappa_{3}}\right)(1-\lambda)-\alpha}{\alpha+\gamma_{T}\left(\left(n r^{e q}\right)^{\kappa_{1}} D^{\kappa_{2}} \rho^{\kappa_{3}}\right)}, \quad \forall i
$$

An informal proof and the intuition behind the equilibrium is discussed in the next subsection. Note first, however, that analogous Propositions and Corollaries exist that demonstrate the need (and potential sufficiency) of a minimum of religious devotion by the congregation and concerning a minimum of financial resources available in order to support a religious equilibrium. In other words, religious observation (in this model) is inherently a group activity-even if we model the rewards as 
individualistic. Thus, even significant moral authority built on the foundational teachings of the church and the quality of its leadership need not be sufficient for an individual to reap the benefits of religious activity (so that in response $r_{i}^{b r}=0$ ) independent of the financial resources of the church.

In this model, unlike most models of moral behavior or altruism (see Laffont 1975, Hollander, 1990, Andreoni, 1990, and Brekke et al. 2003), the public good is the community, and, as such, intangible. While agents concerned with their spiritual growth give of what they have been given, they do not do so to enrich or strengthen the church. However, by living their faith they do strengthen the institution which, in turn, further strengthens their faith.

\subsection{Discussion of the Religious Equilibrium and its Attainment}

Before characterizing and studying the religious equilibrium in detail, we first show how its attainment depends on how one agent's actions are direct responses to the actions of other members in the community, and how-in turn - the individual's actions affect the overall community.

Let $\rho>\underline{\rho}$ be given, so that the church provides a sufficiently strong foundation to allow for a religious equilibrium given the resource and time constraints of the community. We assume that all members of the community-save the individual whose optimal responses we wish to analyze-chose the same level of religious activity. We then seek to determine how the individual responds to this level.

From the agent's first order condition (Equation ??) in conjunction with Assumptions 1 and 2, we know that when the remaining members of the community have religious participation levels that are too low, the agent will not devote any time to religious activities. However (by virtue of the existence of a religious equilibrium) there exists a threshold religious activity level in the community, call this $\tilde{R}$, so that the agent is 
on the verge of participating in religious activity (see Figure 1). Formally, $\gamma_{T}\left(\tilde{R}^{\kappa_{1}} D^{\kappa_{2}} \rho^{\kappa_{3}}\right)(1-\lambda)=\alpha$. For this level, let $\tilde{r}_{-i}$ denote the (symmetric) religious activity of members of the community other than the individual $i$ associated with $\tilde{R}$, that is, $\tilde{r}_{-i}:=\tilde{R} / n$. Then the agent's first order condition (Equation ??) is

$$
r_{i}^{b r}=\frac{\gamma_{T}\left(\left(n \tilde{r}_{-i}\right)^{\kappa_{1}} D^{\kappa_{2}} \rho^{\kappa_{3}}\right)(1-\lambda)-\alpha}{\alpha+\gamma_{T}\left(\left(n \tilde{r}_{-i}\right)^{\kappa_{1}} D^{\kappa_{2}} \rho^{\kappa_{3}}\right)} \equiv 0 .
$$

Thus, despite others being involved in religious activity, the individual does not find it worth his while to take part. However, it is also clear that this choice is in response to what the other members of the community chose to do. Hence, consider now how the individual optimally responds to a change in the others' actions. Specifically, the right-derivative is,

$$
\left(\frac{d}{d r_{-i}}\right)^{+} r_{i}^{b r}\left(r_{-i}\right)=\frac{\gamma_{T}^{\prime} \kappa_{1} \chi \alpha(2-\lambda)}{r_{-i}\left(\alpha+\gamma_{T}\right)^{2}}>0 .
$$

That is, one's own desired religious activity level $r_{i}^{b r}$ increases with the overall level of religious activity in the community. This insight is important in its own right:

Lemma 2 (Multiplier Effects) An agent's optimal choice of religious observance, $r_{i}^{b r}$ is increasing in others' religious activities. That is,

$$
\frac{d}{d r_{-i}} r_{i}^{b r}\left(r_{-i}\right) \geq 0
$$

At levels of $R=n r_{-i}$ at which the agent begins to actively participate in religious activity, the derivative in Lemma 2 is in fact greater than one. Thus, a uniform symmetric increase in religious activity by other members in the community, $r_{-i}$, by one unit of time (e.g., an hour per week), leads to an optimal response of the individual that is greater than one unit of time, e.g., the agent responds by spending more than an hour at religious activities, albeit, still less than the other members of the community do. 
Thus, the agent's religious participation increases more quickly than that of the other members in the community, leading to a convergence in activities. Indeed, at some point all agents in society spend the same amount of time in religious activities, call this level $\hat{r}_{i}=\hat{r}_{-i}=\hat{r}$ (see Figure 1).

Once this level of religious activity is reached, an equilibrium is attained. That is, since $\hat{r}_{i}$ is the optimal individual religious activity level (i.e., the best response) when others are at the same level, society's actions are not only individually optimal, but also mutually consistent. Formally, the condition of religious equilibrium given in Corollary ?? is met at $\hat{r}$, i.e.,

$$
\hat{r}=\frac{\gamma_{T}\left((n \hat{r})^{\kappa_{1}} D^{\kappa_{2}} \rho^{\kappa_{3}}\right)(1-\lambda)-\alpha}{\alpha+\gamma_{T}\left((n \hat{r})^{\kappa_{1}} D^{\kappa_{2}} \rho^{\kappa_{3}}\right)} .
$$

However, this equilibrium is not considered "stable" in the following sense. Because the slope (derivative) of an agent's best response is still greater than unity at this point, if the other members each contribute another hour to religious activity, the individual best responds by increasing his activity by more than an hour-which, in turn, leads to the others optimally further increasing the amount of time they spend in religious activity. ${ }^{4}$ Such propagation slows once the derivative of the best-response function is less than one. However, it does not come to an end until society's actions are again individually optimal and mutually consistent-i.e., a new equilibrium is reached, call this equilibrium level of religious activity $r_{i}^{*}=r_{-i}^{*}=r^{*}$ (see Figure 1 ), again with,

$$
r^{*}=\frac{\gamma_{T}\left(\left(n r^{*}\right)^{\kappa_{1}} D^{\kappa_{2}} \rho^{\kappa_{3}}\right)(1-\lambda)-\alpha}{\alpha+\gamma_{T}\left(\left(n r^{*}\right)^{\kappa_{1}} D^{\kappa_{2}} \rho^{\kappa_{3}}\right)} .
$$

This equilibrium is stable, in the sense that individual deviations lead only to minor responses of others, that are weak enough to make it worthwhile for the deviator to return to the original equilibrium. This stable

\footnotetext{
${ }^{4}$ Conversely, if any agent spends less than $\hat{r}$ in religious activity, all others best respond by reducing their activity levels, and as this is self-perpetuating, society collapses back onto the secular equilibrium given in Proposition ??.
} 
equilibrium is the equilibrium we will henceforth refer to when speaking of the "religious equilibrium."

\subsection{Properties of the Religious Equilibrium}

In light of the preceding discussion, the critical importance of the interrelationship between members of the community is clear. Indeed, attainment of a religious equilibrium is not possible without others to interact with. This has an implication for the quality of the religious equilibrium, as well as individual members' actions, spirituality and wellbeing.

PROPOSITION 2 In the religious equilibrium, an increase in church membership yields higher religious participation by individual members and results in higher levels of spirituality and over-all wellbeing. That is,

$$
\frac{d}{d n} r^{*}>0 ; \quad \frac{d}{d n} \sigma>0 ; \quad \frac{d}{d n} u>0 .
$$

Note that this and the following results are in part represented by an increase in the $r_{i}^{b r}\left(r_{-i}\right)$ function in Figure 1.

Christianity is an evangelical religion, and, as such, Christians by their example of living the Gospels, loving their neighbors as themselves, are supposed to convert others to their beliefs. In our model, that translates into increasing $n$. An increase in the size of the religious community increases each individual member's spirituality by increasing the strength of the faith community and thereby the institutional strength of the church. All, new and old members of the community alike, are made better off. ${ }^{5}$ This improved spiritual and temporal welfare is, in essence, what Pope Benedict is suggesting when he speaks of returning God to the public consciousness and to the center of European culture (Ratzinger, 2005) and of re-evangelizing Europe (Thavis, 2005); what the Anglican

\footnotetext{
${ }^{5}$ Our result is consistent with Lipford (1995) who finds that an increase in the size of a congregation does not induce free riding.
} 
Communion dedicated its Decade of Evangelism to (Carey, 1999), and the center of the vision proclamation of the Assemblies of God (General Council of the AoG, 2000).

Note that thus far the role of church doctrine, i.e., $\rho$ has been discussed as a minimum (necessary, but not sufficient) requirement to obtain the religious equilibrium. However, even when $\rho>\rho$ so that a religious equilibrium is attainable (and attained), church teachings and leadership quality play important roles in the characterization and the "quality" of that equilibrium. Thus,

PROPOSITION 3 In the religious equilibrium, a strengthening of church doctrine and improving the quality of church leadership yields higher religious participation by members and results in higher levels of spirituality and over-all wellbeing. That is,

$$
\frac{d}{d \rho} r^{*}>0 ; \quad \frac{d}{d \rho} \sigma>0 ; \quad \frac{d}{d \rho} u>0 .
$$

The strength and moral authority of a church, which is essential for its ability to coordinate behavior, can be affected by a wide variety of things including conscious decisions to revise foundational beliefs taken by church leaders, behavior of church leaders in ways inconsistent with the received teachings of the church, or changes in society that lead to changes in how church teachings are perceived. Whatever the source of the strength or the cause of its change, churches with stronger more coherent theologies attract adherents, and those with weaker less coherent theologies lose adherents. Thus, the decline in attendance at and membership in Christian churches of all denominations throughout Europe can be explained by church teachings being perceived as less compelling than a secularist alternative, the decline in attendance at mainline Protestant churches in the United States can be explained by fundamental disagreements on church doctrine, for example the schism caused by the 
election of an openly gay Bishop by the U.S. Episcopal Church and the blessing of same sex marriages by the Canadian Anglican Church in contravention of Anglican Communion doctrine (Blair, 2005), and the decline in attendance at the Roman Catholic Church in the United States and Ireland as a result of the pedophilia scandals which exposed the church hierarchy's protection of guilty priests rather than of innocent children (John Jay College of Law, 2005 ; Murphy, et al., 2005).

In addition to church membership and teachings, the resources of the church are also critical in effecting its mission and thus the activities and wellbeing of its members:

PROPOSITION 4 In the religious equilibrium, an increase in the financial resources available to the church yields higher religious participation by members and results in higher levels of spirituality and over-all wellbeing. That is,

$$
\frac{d}{d D} r^{*}>0 ; \quad \frac{d}{d D} \sigma>0 ; \quad \frac{d}{d D} u>0 .
$$

The wealth of one's congregation or church allows it to carry out its ministry of charity to those in need, whether members of the congregation or not. This, as established in the work of Lynch (2003) and de Swaan (1988), strengthens and stabilizes communities, and thereby makes community members better off. These same communities can be weakened, and the wellbeing of their members reduced, by decreases in the temporal wealth of the church as a result, for example, of income taxation which reduces individuals after tax income and thus their ability to give. This weakening and the effects thereof are the case even if the tax revenues are used to provide the same charitable services as were previously provided by the church. de Swaan (1988) suggests that the differential effect arises because of how the funds are provided-if by taxation they are compulsory, while if by donations to the church they are voluntary, and 
because of the distancing of those providing the charitable sources (taxpayers, rather than members of the church) from those receiving them (the poor, rather than members of the church).

Lastly, we consider how secular society affects individual religiosity, spirituality, and overall wellbeing.

PROPOSITION 5 In the religious equilibrium, an increase in the socially minimal 'requirements' on time spent at leisurely activities yields diminished religious participation by members and results in lower levels of spirituality and overall wellbeing. That is,

$$
\frac{d}{d \lambda} r^{*}<0 ; \quad \frac{d}{d \lambda} \sigma<0 ; \quad \frac{d}{d \lambda} u<0
$$

The difficulties inherent in turning away from this world and the demands thereof and toward God have been recognized since Biblical times. See Luke 14: 16-24, where the demands of the world, the activities one engages in to meet and surpass a socio-cultural expectation, also take one away from religious activities. This leads, ultimately, to less rather than greater happiness, since all community members will respond similarly to the worldly demands by reducing religious participation, and then reducing it further in response to the lower level of participation by their peers. This is the important implication of the multiplier effects described in Lemma 2.

\section{The agent's money allocation problem}

Having analyzed the agent's time allocation problem, consider now how money is allocated between competing desires. Again, we consider only cases in which $h=1$ or, equivalently, cases in which the agent's decisions are not affected by the presence of the $h$ multiplier. Let $v(T)$ 
denote the agent's utility associated with time $T$ when it is optimally allocated between leisure $l^{*}$ and religious activities $r^{*}$. Then, analogously to the time allocation problem, one obtains the agent's money allocation problem and solution,

$$
\begin{gathered}
v(T)\left(\frac{M}{p}(1-\bar{d})-\mu\right)^{\beta}(1+\bar{d})^{\gamma_{M}} \rightarrow \max _{\{\bar{d}\}} \text { s.t. } \bar{d} \in[0,1] \\
\Longrightarrow \bar{d}^{b r}=\max \left\{0, \frac{\gamma_{M}\left(1-\frac{p}{M} \mu\right)-\beta}{\beta+\gamma_{M}}\right\} .
\end{gathered}
$$

The solution in Equation ?? resembles that of the time allocation problem given in Equation ??. Notice, however, that the marginal utility from material consumption, $\mu$, is now weighted by (the inverse of) the real value of monetary income.

Similar to Assumption 2, absent a functioning church (i.e., $x=0$ ) marginal utility from material consumption exceeds that of charitable giving. Formally,

Assumption 3 Absent a functioning church, the marginal rate of substitution between charitable giving/donations and material consumption is less than one's real income, i.e.,

$$
\left.\frac{\partial u / \partial \bar{d}}{\partial u / \partial m}\right|_{\chi=0}<\frac{M}{p}
$$

Given this structure, the analysis of equilibrium is analogous to that of time allocation, with the Pareto-superior religious equilibrium being characterized by,

$$
\bar{d}^{*}=\frac{\gamma_{M}\left(R^{\kappa_{1}}\left(n M \bar{d}^{*}\right)^{\kappa_{2}} \rho^{\kappa_{3}}\right)\left(1-\frac{p}{M} \mu\right)-\beta}{\beta+\gamma_{M}\left(R^{\kappa_{1}}\left(n M \bar{d}^{*}\right)^{\kappa_{2}} \rho^{\kappa_{3}}\right)} .
$$

Moreover, all of the results derived for the individual and for the community concerning religious activity carry over mutatis mutandis for 
the equilibrium with charitable giving. Of the analogous results, the one most noteworthy is that concerning (perceived or actual) pressures put on the individual by secular society. That is, the parallel to Proposition ??:

PROPOSITION 6 In the religious equilibrium, an increase in the socially minimal 'requirements' on material consumption yields diminished religious donations by members and results in lower levels of spirituality and overall wellbeing. That is,

$$
\frac{d}{d \mu} r^{*}<0 ; \quad \frac{d}{d \mu} \sigma<0 ; \quad \frac{d}{d \mu} u<0 .
$$

The difficulties faced by the rich in getting into heaven are found throughout the synoptic Gospels, as is evident from Mark 10: 23-25, Matt 13: 18-23, Luke 6: 24, or Luke 18: 18-24. They all suggest that the pull of the comforts of this life, more available to the rich than the poor, are a distraction from dedicating oneself and one's wealth to achieving the riches of the next life. But this accumulation of goods also fails to provide happiness in this life. In the middle ages the problem of riches was recast in terms of greed or avarice. The problem here was not wealth in and of itself, but an excess of wealth not shared with those less fortunate (Newhauser, 2000), thus leading to the breakdown of the social order, as is also suggested by Lynch (2003) and de Swaan (1988). This tension between glorifying oneself in this world, by consuming more than one's peers (more than $\mu$ ) and providing for the next by higher donations relative to one's income, appears a constant in the human condition. In contrast to religious activity, individual spirituality responds to charitable giving relative to one's income, rather than absolute amounts of donations. And this difference yields some additional insights about individual wellbeing and the religious community. 
PROPOSITION 7 In the religious equilibrium, an increase in the financial resources available to the individual, yields greater relative donations by members and results in higher levels of spirituality and over-all wellbeing. That is,

$$
\frac{d}{d M} \bar{d}^{*}>0 ; \quad \frac{d}{d M} \sigma>0 ; \quad \frac{d}{d M} u>0 .
$$

As income rises, so do donations to the church, the more one has to share, the more one shares. Further, the higher the wealth of the church, $D$, all else equal, and thus the better able the church is to fulfill its pastoral missions, the better off the members of the church-and the more, again, members are willing to give, resulting from further multiplier effects.

However, the source of those funds does matter. So suppose, as in many European countries, individuals' incomes are taxed, reducing $M$, and those tax revenues are used to fund churches. Suppose prior to the imposition of the tax the wealth of the church is $\hat{D}$, and the government agrees to maintain this level of funding after the tax and the government further agrees that it will tax no more than is needed to maintain $\hat{D}$. Then, because individuals' income has fallen, they will reduce their donations, taxes will have to be increased to compensate, and this process can continue until the entire funding of the church is provided by the state: $D=d_{S}$. Even though the wealth of the church is maintained, members of the faith community are made worse off: their own spirituality and their personal happiness are unambiguously diminished. This mirrors Andreoni (1990), but here it is not the warm glow of giving that is lost but one's personal investment in faith and one's attachment to one's faith community. 


\section{The Role of an Effective Church}

As stated at the outset, the church, compared to the state, is well-placed to provide a coordinating function, which may assure the attainment of the Pareto-superior equilibrium. It does so by providing incentives. ${ }^{6}$ These incentives can be positive (rewards) - the eschatological benefits of the Kingdom of God. And negative (punishments)—consider, e.g., Matt 13:40-42 or Mark 8:38.

Also, the church institutes rituals, communal gatherings for prayer and reflection in which beliefs held in common are reiterated, and, for Christians, in the reaffirmation of their oneness with Christ. That is, the church reminds its members that they have obligations to their fellow men and in considering themselves they must consider all others as well, since they together, form the church, which, divided against itself (when coordination fails) cannot stand. In practical (coordinating) terms the church can make its members aware that their actions affect others, even others they do not know and who do not know them.

However, to the extent that church leaders are able to coordinate community actions, they may even be able to induce individuals to behave specifically as a member of the community, and thus in a socially optimal, rather than in an individually optimal, manner. In so doing, the church can cause agents to each act for the greater good, i.e., as 'social planners,' and thereby lead the community to a Pareto optimal outcome-the best outcome for all agents individually as well as communally. ${ }^{7}$

Theorem (Pareto-Optimality) Pareto-optimality is achieved-and thus overall societal and individual wellbeing are maximized-at levels of religious

\footnotetext{
${ }^{6}$ Brams and Kilgour (2002) find that a certain day of reckoning, no matter how far in the future, induces good behavior today. Hull and Bold (1989) consider the eschatological rewards and punishments as enforcement mechanisms. We consider them, instead, as incentives for and indicators of ideal behavior.

${ }^{7}$ Guiso, et al. (2003) show that Christians exhibit behaviors conducive to economic growth, a macroeconomic indicator of welfare. Our results suggest why theirs may obtain.
} 
activity and donations that exceed the (decentralized) individual optimal levels of the Pareto-superior religious equilibrium. That is,

$$
\begin{gathered}
u\left(\cdot, \sigma\left(r^{* *}, \bar{d}^{* *}\right)\right)>u\left(\cdot, \sigma\left(r^{*}, \bar{d}^{*}\right)\right), \\
\text { with } r^{* *}>r^{*}, \text { and } \bar{d}^{* *}>\bar{d}^{*},
\end{gathered}
$$

where $r^{* *}$ and $\bar{d}^{* *}$ are the individual levels of religious activity and donations that maximize

$$
(l-\lambda)^{\alpha}(m-\mu)^{\beta} h(1+r)^{\gamma_{T}(x(r, M \bar{d}))}(1+\bar{d})^{\gamma_{M}(x(r, M \bar{d}))}
$$

The church's prescribed solution suggests that all members of the community should engage in a level of religious activity and donations in excess of the individually optimal level (i.e., $r^{* *}>r^{*}$ and $\bar{d}^{* *}>\bar{d}^{*}$ ), because of the positive external effects of their actions on others (see the multipliers in Lemma 2 and the supporting discussion). The church then exhorts its members to this level of activity by revealing the positive effects of individuals' actions one on the other, thereby revealing what in the market would remain hidden. Whenever the church is able to do this, Pareto optimality can be achieved. That is, while individuals would like to alter their behavior, given what others are doing in the Pareto-optimal state (i.e., $r_{i}^{b r}\left(r_{-i}^{* *}\right)<r^{* *}$ and $\bar{d}_{i}^{b r}\left(\bar{d}_{-i}^{* *}\right)<\bar{d}^{* *}$ ), they recognize that the overall effect of individual best-responses (Corollary ??), is strictly dominated by following church recommendations.

The church can obtain this outcome through moral suasion, or it can resort to a formalization of the $h$-function discussed earlier, i.e., $r_{\min }(\rho)=r^{* *}$ and $\bar{d}_{\min }(\rho)=\bar{d}^{* *}$. Although this threat of hell is coercive, all agree that the prescribed behavior is optimal, and would readily agree to the coercion. Thus, concerning donations, e.g., in the Old Testament individuals are commanded to tithe, since one tenth of their wealth is the Lord's portion: 
"When you have finished paying all the tithe of your produce in the third year, which is the year of tithing, giving it to the Levite, the sojourner, the fatherless, and the widow, that they may eat within your towns and be filled.” [Deut 26:12]

And in the New Testament individuals are commanded to give to God what is God's:

Jesus said to them, "Render to Caesar the things that are Caesar's, and to God the things that are God's." [Mark 12:17a]

These specific recommendations can be thought of as providing a level of donations great enough to insure against the coordination failure equilibrium outcome. But they may be more than that, and rather set a level of donations, explicitly or implicitly, that will lead to the Pareto optimal coordinated outcome.

The great potential of the Church, compared to the State, in modern Western societies, thus becomes clear, for it is incompatible with modern views of a free society that individuals be forced to the degree possibly required to achieve the Pareto efficient outcome (especially when it comes to one's time) by means of the force of the State. Yet, rather than the State's force, the Church's power to use coercion is voluntary and acceptable. Yet, herein also lies the challenge to the Church in Western (increasingly secular) societies, for it is easier for the individual to freeride within or even leave the Church than it is for him free-ride in or to leave the State.

\section{Conclusion}

The church has played a central role in establishing and maintaining, as well as, perhaps inadvertently, undermining, communities throughout modern history. Yet today it finds itself often on the periphery, less 
able to build communities of faith and to minister to the wider community. In this paper we explore some of the mechanisms through which churches can coordinate individual behavior so as to achieve improvements in individual and social welfare, and in so doing reveal the ways in which churches can fail, causing established communities to founder or dissolve.

In our model of community formation inherently religious individuals may become trapped in a secular equilibrium because no one else practices, or because what is offered by a church is less than what is offered by secular society because of the weakness or incoherence of church teachings, poverty, or lack of adherents. These secular equilibria are strictly dominated by a religious equilibrium in which individuals' actions bestow positive external benefits on other community members. Churches reveal the benefits of coordinated behavior, both in this world and in the world to come, and the costs of uncoordinated behavior, separation from God and one's fellow man, to induce community members to take actions which are both individually and socially (communally) beneficial.

The power of the church's exhortations is diminished by doctrinal weakness, which can have its source in the doctrine itself, how that doctrine is interpreted, applied, or perceived, or how that doctrine is communicated. The rapid growth of the so called Evangelical Christian (Protestant) Churches in the United States, and the decline of the so called Mainline Protestant Churches have been attributed to doctrinal strength in the former and weakness in the latter. The decline in religious practice in Europe may be attributed to issues of doctrine and to the ceding to or crowding out by the State what had once been the provenance of the Church, such as the provision of charity for the poor, and other socialwelfare programs for the community at large. Additionally, funding of the Church by the State, as is found in many European countries, can erode the benefits of membership in one's faith community, and, per- 
haps, lead to the dissolution of the community (reversion to the secular equilibrium).

Churches have proven themselves to be very resilient institutions which can play a vital role in strengthening communities. Whether they can continue to do so depends on what they can offer to those struggling to meet the demands of this world, in a world in which many of their traditional ministries have been ceded to the State, and in a world in which their teachings are often perceived to be at variance with rather than the source of shared cultural beliefs. The challenge to churches today is great, but the benefit to society of their succeeding may be greater still. 


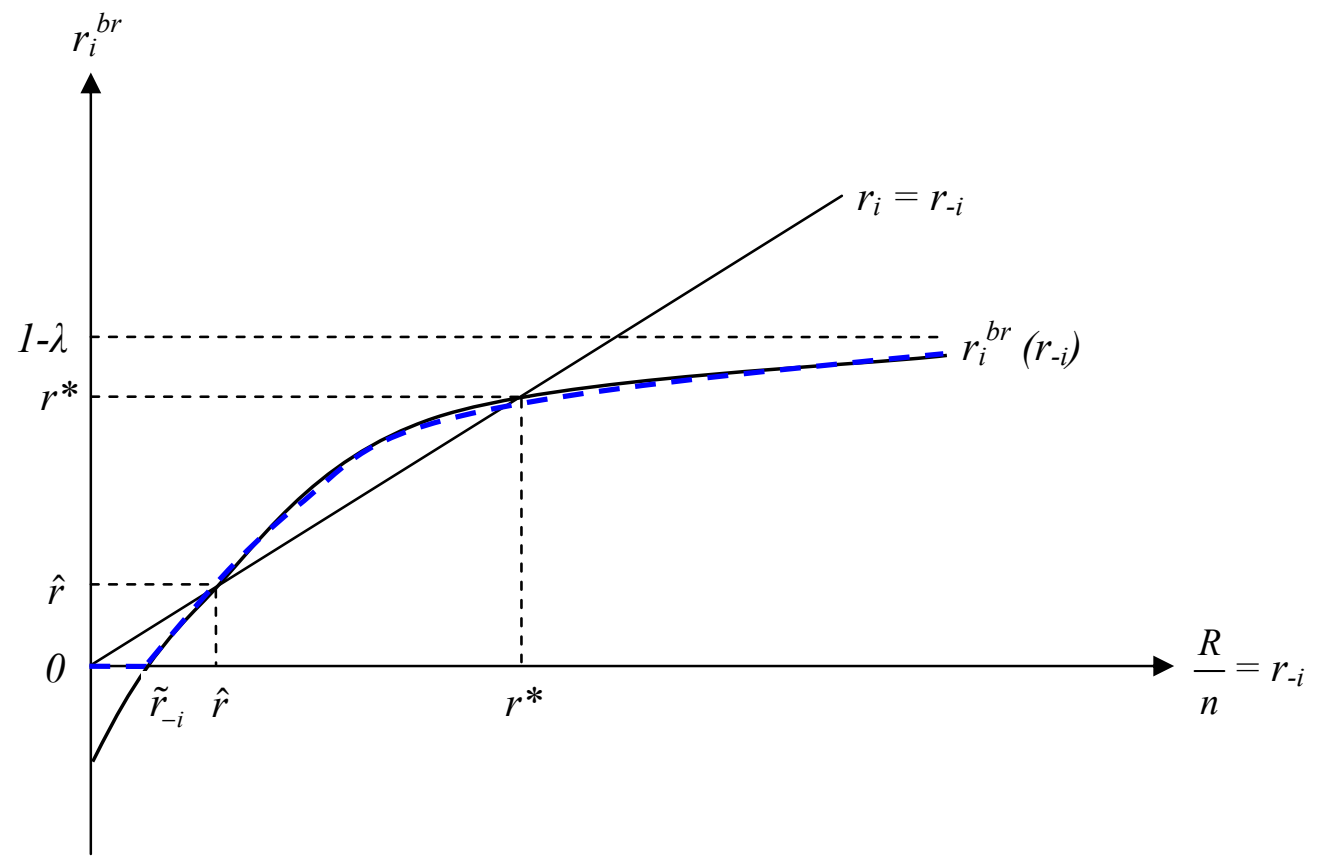

FIGURE 1: The individual's optimal amount of time devoted to religious activities (thick dashed line) as a function of other members' time allocation. There is a (stable) secular equilibrium in the origin, the (stable) religious equilibrium is given by $r^{*}$. 


\section{Appendix: Proofs}

PROOF OF LEMMA 1 Given the time constraint (??), the agent engages in religious activity only if the marginal utility from doing so is greater than or equal to the marginal utility from leisure time.

Proof of Proposition ?? Assumption 2 implies that $\left.\frac{\gamma t}{\alpha} \frac{l-\lambda}{1+r}\right|_{\chi=o}<1$, or

$$
\gamma_{T}(0)<\alpha \frac{1+r}{l-\lambda}, \quad \forall r, l
$$

By Assumption 1, $\gamma_{T}$ is strictly increasing and therefore has a strictly increasing inverse, call this $\gamma_{T}^{-1}$. It follows from Equation ?? that $0<$ $\gamma_{T}^{-1}\left(\alpha \frac{1+r}{l-\lambda}\right)$. Moreover, since $\gamma_{T}^{-1}$ is increasing, we have

$$
\gamma_{T}^{-1}\left(\alpha \frac{1+r}{1-\lambda-r}\right)>0
$$

Let $\bar{R}$ and $\bar{D}$ be given and define $\bar{r}=\bar{R} / n$ as the average contribution necessary to obtain $\bar{R}$. Now let

$$
\left.\underline{\rho}\right|_{\bar{R}, \bar{D}}=\left(\frac{\gamma_{T}^{-1}\left(\alpha \frac{1+\bar{\gamma}}{1-\lambda-\bar{r}}\right)}{\bar{R}^{\kappa_{1}} \bar{D}^{\kappa_{2}}}\right)^{1 / \kappa_{3}},
$$

and note by Equation ?? that $\underline{\rho}>0$. Note finally that for all $\rho^{\prime}<\underline{\rho}$, Equation ?? can be rewritten as

$$
\frac{\gamma_{T}\left(\bar{R}, \bar{D}, \rho^{\prime}\right)(1-\lambda)-\alpha}{\alpha+\gamma_{T}\left(\bar{R}, \bar{D}, \rho^{\prime}\right)}<\bar{r},
$$

which, by Equation ??, indicates that the agents' chosen time in religious activities is insufficient to sustain $\bar{R}$ given $\rho^{\prime}$ so that no religious equilibrium exists for any $\rho<\underline{\rho}$, given $\bar{R}$ and $\bar{D}$.

PROOF OF COROLlary ?? The unique equilibrium at $\rho=\underline{\rho}$ follows directly from the proof of the proposition. The remainder is the standard proof for coordination games. See, e.g., Cooper (1999). 
PROOF OF LEMMA 2 Noting that for all $r_{-i}<\tilde{r}_{-i}$ the best individual response is $r_{i}^{b r}=0$, we obtain the equality of the lemma. The inequality follows from extending Equation ?? to the rest of the domain.

Proof OF Proposition ??

1. Rewriting Equation ?? gives the implicit equilibrium condition as,

$$
G\left(r^{*}, \cdot\right)=\frac{\gamma_{T}\left(\left(n r^{*}\right)^{\kappa_{1}} D^{\kappa_{2}} \rho^{\kappa_{3}}\right)(1-\lambda)-\alpha}{\alpha+\gamma_{T}\left(\left(n r^{*}\right)^{\kappa_{1}} D^{\kappa_{2}} \rho^{\kappa_{3}}\right)}-r^{*}=0 .
$$

Hence, recalling that $\chi=\left(n r^{*}\right)^{\kappa_{1}} D^{\kappa_{2}} \rho^{\kappa_{3}}$,

$$
\frac{d}{d n} r^{*}=-\frac{G_{n}}{G_{r^{*}}}=\frac{\frac{\gamma_{T}^{\prime} \kappa_{1} \chi \alpha(2-\lambda)}{n\left(\alpha+\gamma_{T}\right)^{2}}}{1-\frac{\gamma_{T}^{\prime} \kappa_{1} \chi \alpha(2-\lambda)}{r^{*}\left(\alpha+\gamma_{T}\right)^{2}}}>0,
$$

where the inequality follows, because at the stable Pareto-dominant equilibrium, the slope of the derivative of the best-response function (See Equation ??) is less than 1, making the denominator positive.

2. The agent's spirituality $\sigma$ is increasing in the number of active congregants $n$, because $\sigma$ is increasing in both $\gamma_{T}$ (which is increasing in $n$-see Assumption 1 in conjunction with Equation ?? and the definition of $R$ ), and in $r_{i}^{*}$, which was just shown to be increasing in $n$.

3. Due to multiplier effects (Lemma 2), an exogenous increase in $\chi$ due to an increase in $n$ increases the agent's utility at his initial choice of $r_{i}$. His utility is then further increased by re-optimizing his religious activity.

Proof OF PROPOSITION ?? Using Equation ??, similar to the proof of Proposition ?? one has,

$$
\operatorname{sign}\left(\frac{d}{d \rho} r^{*}\right)=\operatorname{sign}\left(G_{\rho}\right)=\operatorname{sign}\left(\frac{\gamma_{T}^{\prime} \kappa_{3} \chi \alpha(2-\lambda)}{\rho\left(\alpha+\gamma_{T}\right)^{2}}\right)>0 .
$$


The other arguments follow as in the proof to Proposition ??

ProOf OF PROPOSITION ?? The proof follows mutatis mutandis from the proofs of Propositions ?? and ??

Proof of Proposition ?? Similar to the previous proofs,

$$
\operatorname{sign}\left(\frac{d}{d \lambda} r^{*}\right)=\operatorname{sign}\left(G_{\lambda}\right)=\operatorname{sign}\left(\frac{-\gamma_{T}}{\alpha+\gamma_{T}}\right)<0
$$

PROOF OF PROPOSITION ?? The proof follows along the lines of the proof to Proposition ??

ProOf OF Proposition ?? The proof is analogous to those of Propositions ?? and ??.

ProOF of THEOREM The proof is an implication of multiplier effects and follows readily.

\section{References}

Andreoni, J., 1990, "Impure Altruism and Donations to Public Goods: A Theory of Warm Glow Giving,” Economic Journal, 100, 464-77.

Barro, R., and D. Gordon, 1983, “A Positive Theory of Monetary Policy in a Natural Rate Model,” Journal of Political Economy, 91, 589-610.

Bartchy, S.S., 2002, “Divine Power, Community Formation, and Leadership in the Acts of the Apostles," in Community Formation in the Early Church and in the Church Today, R.N. Longenecker, ed., 89104. Peabody, MA: Hendrickson Publishers.

Blair, E., 2005, “Rowan Urges Split Church to Keep Talking,” Reuters. 28 October. 
Blanchflower, D.G., and Oswald, A.J., 2004, "Well-Being over Time in Britain and the USA," Journal of Public Economics, 88, 1359-86.

Bonhoeffer, D., 1959, The Cost of Discipleship. New York: Simon \& Schuster.

Brams, Steven J., and Kilgour, D. Marc, 2002, "Games that End in a Bang or a Whimper," in George Ellis (ed.), The Far Future Universe. Radnor, PA: Templeton Foundation Press, 196-206.

Brekke, K.A., Kverndokk, S., and Nyborg, K., 2003, “An Economic Model of Moral Motivation," Journal of Public Economics, 87, 1967-83.

Brown, P., 1981, The Cult of the Saints: Its Rise and Function in Latin Christianity. Chicago: Chicago University Press.

Carey, George, 1999, “Prophetic Evangelism-Glory and Gift,” Address by the Archbishop of Canterbury to the Anglican Conference on Evangelism 1999. Swanwick, UK.

Catholic Church, 2003, Catechism of the Catholic Church, 2nd edition. New York: Doubleday.

Cooper, R.W., 1999, Coordination Games: Complementarities and Macroeconomics. Cambridge University Press, Cambridge UK.

deSwaan, A., 1988, In Care of the State: Health Care, Education and Welfare in Europe and the USA in the Modern Era. New York: Oxford University Press.

Diamond, D.W. and P.H. Dybvig, 1983, "Bank Runs, Deposit Insurance, and Liquidity," Journal of Political Economy 91, 401-419.

Drucker, P.F., 1998, “Management’s New Paradigms,” Forbes. October 5.

Elshtain, J.B., 2001, "Faith of Our Fathers and Mothers: Religious Belief and American Democracy," in Religion in American Public Life: Living with Our Deepest Differences A.Y. al-Hibri, J.B. Elshtain, and C.C. 
Haynes., eds., 39-61. New York: W.W. Norton \& Company.

Farnell, R., 2001, “Faith Communities, Regeneration and Social Exclusion:

Developing a Research Agenda," Community Development Journal, $36,263-272$.

General Council of Assemblies of God, 2000, Our Vision 2000 Proclamation. August 11.

Gruber, J., 2005, “Religious Market Structure, Religious Participation, and Outcomes: Is Religion Good for You?” Advances in Economic Analysis \& Policy, 5(1): Article 5.

Guiso, L., Sapienza, P., and Zingales, L., 2003, "People’s Opium? Religion and Economic Attitudes," Journal of Monetary Economics, 50, 225-82.

Hayes, A.L., 2002, "Christian Ministry in Three Cities of the Western Empire," in Community Formation in the Early Church and in the Church Today, R.N. Longenecker, ed., 129-156. Peabody, MA: Hendrickson Publishers.

Hester, D.C., 2002, “The Sanctified Life in the Body of Christ: A Presbyterian Form of Christian Community," in Community Formation in the Early Church and in the Church Today, R.N. Longenecker, ed., 194-212. Peabody, MA: Hendrickson Publishers.

Hobbes, Th., 1958 [1651], Leviathan Parts I and II. Indianapolis: The Bobbs-Merrill Company, Inc.

Hollander, H., 1990, “A Social Exchange Approach to Voluntary Cooperation," American Economic Review, 80, 1157-67.

Hull, B.B., and F. Bold, 1989, "Towards an Economic Theory of the Church," International Journal of Social Economics, 16, 5-15.

John Jay College of Criminal Justice, 2005, The Nature and Scope of Sexual Abuse of Minors by Catholic Priests and Deacons in the United States 
1950-2002. Washington, D.C.: United States Conference of Catholic Bishops.

Johnson, L.T., 1998, Religious Experience in Earliest Christianity. Minneapolis: Fortress Press.

Knuth, E.T., 1992, “The Beguines,” mimeo., St. John's University, Collegeville, $\mathrm{MN}$.

Kyland, F., and E. Prescott, 1977, "Rules Rather than Discretion: The Inconsistency of Optimal Plans," Journal of Political Economy, 85, 47392.

Laffont, J.-J., 1975, “Macroeconomic Constraints, Economic Efficiency and Ethics: An Introduction to Kantian Economics," Economica, 42, 43037.

Lipford, J. W., 1995, “Group Size and the Free-Rider Hypothesis: An Examination of New Evidence from Churches," Public Choice, 83, 291-303.

Lynch, K.A., 2003, Individuals, Families, and Communities in Europe, 1200-1800: The Urban Foundations of Western Society. Cambridge: Cambridge University Press.

Marshall, I.H., 2002, "Congregation and Ministry in the Patoral Epistles," in Community Formation in the Early Church and in the Church Today, R.N. Longenecker, ed., 105-128. Peabody, MA: Hendrickson Publishers.

McDonnell, E.W., 1954, The Beguines and Beghards in Medieval Culture: With Special Emphasis on the Belgian Scene. New Brunswick, N.J.: Rutgers University Press.

Modood, T., 1999, Ethnic Diversity and Public Policy in Britain, ESRC Award R000222124: End of Award Report, University of Bristol, UK. Murphy, F.D., Buckley, H., Joyce, L., 2005, The Ferns Report, Dublin: Gov- 
ernment Publications. October.

New Revised Standard Version Bible, 1989, Grand Rapids: Zondervan.

Newhauser, R., 2000, The Early History of Greed: The Sin of Avarice in Early Medieval Thought and Literature, Cambridge: Cambridge University Press.

Peters, M., 1991, “The Beguines: Feminine Piety Derailed,” Spirituality Today, 43, 36-52.

Ratzinger, J., 2005, “On Europe’s Crisis of Culture,” Zenit News Agency, 26-29 July.

Scott, B.B., 1989, Hear Then the Parable: A Commentary on the Parables of Jesus. Minneapolis: Fortress Press.

Smith, G., 2002, "Religion, and the Rise of Social Capitalism: the Faith Communities in Community Development and Urban Regeneration in England," Community Development Journal 37, 167-177.

Thavis, J., 2005, “Pope, in Spotlight, Outlines Priorities, Style of Emerging Papacy," Catholic News Service, 22 August.

Tirole, J., 1996, “A Theory of Collective Reputation (with Applications to the Persistence of Corruption and to Firm Quality)," Review of Economic Studies, 63(1):1-22.

Volf, M., 2002, “Community Formation as an Image of the Triune God: A Congregational Model of Church Order and Life," in Community Formation in the Early Church and in the Church Today, R.N. Longenecker, ed., 113-138. Peabody, MA: Hendrickson Publishers.

Webster, J., "The "Self-Organizing” Power of the Gospel: Episcopacy and Community Formation," in Community Formation in the Early Church and in the Church Today, R.N. Longenecker, ed., 179-194. Peabody, MA: Hendrickson Publishers. 
Weil, P., 1989, "Increasing Returns and Animal Spirits," American Economic Review, 79(4):889-94.

Young, F., 2002, "Ministerial Forms and Functions in the Church Communities of the Greek Fathers," in Community Formation in the Early Church and in the Church Today, R.N. Longenecker, ed., 157-178. Peabody, MA: Hendrickson Publishers.

Ziegler, J., 1986, “Some Questions Regarding the Beguines and Devotional Art," Vox Benedictina, October. 